\title{
PENGARUH PENYULUHAN KESEHATAN TERHADAP KESIAPSIAGAAN MENGHADAPI BENCANA GEMPA BUMI PADA SISWA SMPN 13 PADANG
}

\author{
Revi Neini Ikbal ${ }^{1}$, Rebbi Permata Sari ${ }^{2}$ \\ ${ }^{1,}$ STIKes Alifah, Jln.Khatib Sulaiman No.52B, Padang, 25000, Indonesia \\ Email: revineini@gmail.com \\ ${ }^{2,}$ STIKes Alifah, Jln.Khatib Sulaiman No.52B, Padang, 25000, Indonesia \\ Email: rebbi.permatasari@gmail.com
}

\begin{abstract}
ABSTRAK
Penelitian ini bertujuan untuk mengetahui pengaruh penyuluhan kesehatan terhadap kesiapsiagaan menghadapi bencana gempa bumi pada Siswa SMPN 13 Padang. Jenis penelitian ini menggunakan Quasi Eksperiment dengan rancangan kelompok tunggal one grouppreretest-posttest design. Pengumpulan data dilakukan di SMPN 13 Padang pada bulan juni- Februari 2018.Populasi seluruh siswa SMPN 13 Padang. pengambilan sampel purposive sample sebnyak 75 orang. Analisi yang digunakan univariat dan bivariat dengan UJI T. Hasil penelitian ini rata-rata kesiapsiagaan Siswa SMPN13 Padang dalam menghadapi bencana gempa bumi sebelum diberikan penyuluhan adalah 17,36 dan rata-rata KesiapsiagaanSiswa SMPN13 Padang setelah diberikan penyuluhan adalah 56,20 dan ada pengaruh atau perbedaan yang singnifikan antara pengukuran kesiapsiagaan menghadapi bencana pada Siswa SMPN 13 Padang dengan nilai $p$ value 0,000. Dapat disimpulkan Ada pengaruh atau perbedaan yang singnifikan antara pengukuran kesiapsiagaan menghadapi bencana pada Siswa SMPN 13 Padang pada pegukuran pertama dan kedua. Diharapkan kepada pihak sekolah SMPN 13 Padang membentuk tim siapsiaga bencana dan meningkatan keterampilan siswaterhadap mitigasi bencana.
\end{abstract}

Kata Kunci: Penyuluhan Kesehatan, Kesiapsigaan Bencana

\begin{abstract}
ABSTRACK
This study aims to determine the effect of health counseling on preparedness to face an earthquake disaster on students SMPN 13 of Padang. This type of research uses Quasi Experiment with the design of a single group one group pre-test design. Data collection was carried out at SMPN 13 Padang in June-February 2018. The population of all students was SMP 13 Padang. purposive sample collection of 75 people. The analysis used univariate and bivariate with Test T. The results of this study the average student preparedness SMPN 13 of Padang in dealing with earthquake disasters before being given counseling was 17.36 and the average Student Preparedness of SMP 13 Padang after being given counseling was 56.20 and there was influence or a significant difference between the measurement of disaster preparedness for students of SMPN 13 Padang with a $p$ value of 0,000. It can be concluded that there is a significant influence or difference between disaster preparedness measurement for students of SMP 13 Padang in the first and second measurements. It is expected that the schools of SMPN 13 Padang form a disaster preparedness team and increase student skills towards disaster mitigation.
\end{abstract}

Keywords: Health Counseling, Disaster Preparedness 


\section{PENDAHULUAN}

Indonesia merupakan Kepulauan Nusantara berada dalam zona tektonik dan gunung api sehingga sangat rawan terjadinya bencana. Ini merupakan tanggung jawab dan kewajiban pemerintah dalam melakukan antisipasi bencana baik sebelum atau sesudah terjadinya suatu bencana (Pranajati, 2013).

Pemerintah melakukan berbagai upaya pengurangan resiko bencana dengan dikeluarkannya Undang-undang tentang Penanggulangan Bencana (BNPB, 2007) dan Peraturan Kepala Badan Nasional Penanggulangan Bencana Nomor 4 Tahun 2008 tentang Pedoman Penyusunan Rencana Penanggulangan Bencana (BNPB, 2008). Berdasarkan PERATURAN Menteri Energi dan Sumber Daya Mineral Republik Indonesia Nomor 11 Tahun 2016 ditetapkan jenis bencana terutama geologi atas beberapa diantaranya ; Gunung api, Gempa Bumi, Tsunami dan Gerakan Tanah. Khususnya derah Sumatera Barat yang menjadi prioritas utama untuk penanggulangan bencana adalah gempa bumi (BNPB, 2008).

Ancaman gempa bumi mendapat perhatian yang luas, karena sifatnya mendadak, dapat diprediksi namun sulit ditentukan waktu terjadinya (Andri Nurudin, 2015). Menurut catatan sejarah dalam kurun waktu setengah abad terakhir tercatat terjadi puluhan bencana alam gempa bumi merusak kawasan pesisir pantai Indonesia. Beberapa kali gempa besar di Indonesia dengan selang waktu yang tidak terlalu lama telah meluluh lantakkan wilayah Indonesia, yaitu gempa dan tsunami aceh pada tanggal 26 Desember 2004. Gempa berkekuatan 8,9 SR di Samudera Indonesia, $32 \mathrm{~km}$ dan pantai Meulaboh Aceh Barat (Syafrizal, 2013). Gempa dasyat juga terjadi di Sumatera Barat juga terjadi pada tanggal 30 September 2009 di lepas pantai Sumatera, sekitar $50 \mathrm{~km}$ barat laut Kota Padang Menurut data Satkorlak PB, sebanyak 1.117 orang tewas akibat gempa ini yang tersebar di 3 kota dan 4 kabupaten di Sumatera Barat, korban luka berat mencapai 1.214 orang, luka ringan 1.688 orang, korban hilang 1 orang. Sedangkan 135.448 rumah rusak berat, 65.380 rumah rusak sedang, dan 78.604 rumah rusak ringan (Konsorsium Pendidikan Bencana, 2011).

Faktor utama yang mengakibatkan timbulnya banyak korban akibat bencana gempa adalah karena kurangnya kesiapsiagaan masyarakat tentang bencana dan kurangnya kesiapan masyarakat dalam mengantisipasi bencana tersebut. Faktor utama yang menjadi kunci kesiapsiagaan adalah pengetahuan, sikap dan kepedulian siap siaga dalam menghadapi bencana. Kesiapsiagaan merupakan salah satu proses manajemen bencana, pentingnya kesiapsiagaan merupakan salah satu elemen penting dari kegiatan penurangan resiko terjadinya bencana (Firmasnyah, 2014).

Banyak upaya yang dapat dilakukan untuk meminimalkan banyaknya korban saat terjadinya gempa bumi, korban jiwa yang paling banyak adalah wanita dan anak-anak. Salah satunya dengan melakukan penyuluhan kesehatan keberbagai Instansi , lembaga serta masyarakat yang ada terutama Sekolah. Sekolah dapat berfungsi sebagai media informasi efektif untuk mengubah pola pikir dan pola prilaku masyarakat dengan memberikan pendidikan pengurangan resiko bencana di sekolah.

Penelitian yang dilakukan oleh Riedel, dkk tahun 2015 melaporkan terdapat pengaruh penyuluhan kesehatan terhadap kesiapsiagaan menghadapi bencana gempa bumi pada siswa SMP Kristen Kakaskasen Kota Tumohon. Penelitian ini akan memperkuat peneliti untuk melanjutnya penelitian ini dikarenakan sangat pentingnya kesiapsiagaan bencana gempa bumi di Kota Padang khsusnya anak-anak untuk menghindari resiko banyak korban.

Sumatera Barat merupakan salah satu provinsi di pulau Sumatera yang rawan terjadinya gempa bumi karena berbatasan langsung dengan lautan Hindia. Kota Padang yang merupakan ibu kota provinsi juga menjadi daerah yang rawan akan bencana gempa bumi. Khususnya sekolah-sekolah di Kota Padang saat sekarang memang menjadi suatu program yang harus dilakukan kegiatan penyuluhan kesiapsiagaan bencana oleh pemerintah. Oleh karena itu peneliti tertarik melakukan penelitian dengan judul "Pengaruh penyuluhan kesehatan terhadap kesiapsiagaan menghadapi bencana gempa bumi pada Siswa SMP 13 Padang”.

\section{METODA PENELITIAN}

Jenis penelitian ini menggunakan Quasi Eksperiment dengan rancangan yang digunakan adalah rancangan kelompok tunggal one group preretest-posttest designPenelitian ini dilakukan di SMPN 13 Padang pada bulan Januari sampai dengan April tahun 2018. Populasi dalam penelitian ini adalah semua siswa yang ada di SMPN 13 Padangdan sampel sebanyak 83 orang, yang terdiri dari siswa kelas VII dan VIIIdengan purposive samplingdengan kriteria inklusi Bersedia menjadi responden dan Siswa kelas VII dan VIII. Pengolahan data melalui analisa data secara univariat dan bivariat menggunakan uji T-Tes Dependent

\section{HASIL}

\section{a. Analisa Univariat}

Analisis univariat digunakan untuk mengetahui ratarata dari masing-masing variabel yang diteliti, bertujuan 
untuk menjelaskan atau mendiskripsikan karakteristik setiap variabel penelitian. Variabel independen adalah pemberian jus semangka dan variabel dependen adalah kesiapsiagaan siswa mengahdapi bencana, sebagai mana terlihat pada tabel berikut ini :

\section{Distribusi Kesiapsiagaan Siswa Menghadapi Bencana Gempa Bumi Sebelum Diberikan Penyuluhan}

Tabel 3.1

Distribusi Kesiapsiagaan Siswa Menghadapi Bencana Gempa Bumi Sebelum Diberikan Penyuluhan

\begin{tabular}{ccccccc}
\hline Variabel & $\mathrm{N}$ & Mean & SD & $\begin{array}{c}\text { Min- } \\
\text { Maks }\end{array}$ & \multicolumn{2}{c}{$95 \%$ CI } \\
\hline $\begin{array}{c}\text { Kesiapsiaga } \\
\text { an Siswa }\end{array}$ & 75 & 17.36 & 3.46 & $9-26$ & 16.56 & 18.16 \\
\hline
\end{tabular}

Berdasarkan tabel 3.1 didapatkan rata-rata kesiapsiagaan Siswa SMPN13 Padang dalam menghadapi bencana gempa bumi pada pretest adalah 17,36 dengan Standar Deviasi 3,46 dengan tingkat pengetahuan yang rendah 9 dan tertinggi 26. Hasil estimasi dapat disimpulkan bahwa 95\% diyakini ratarata kesiapsiagaan siswa dalam menghadapi bencana gempa bumi adalah antara 16,56 sampai dengan 18,16 .

2. Distribusi Kesiapsiagaan Siswa Menghadapi Bencana Gempa Bumi Sesudah Diberikan Penyuluhan

Tabel 3.2

Distribusi Kesiapsiagaan Siswa Menghadapi Bencana Gempa Bumi Sesudah Diberikan Penyuluhan

\begin{tabular}{ccccccc}
\hline & & & & & \multicolumn{2}{c}{$95 \%$ CI } \\
\cline { 5 - 7 } Variabel & N & Mean & SD & $\begin{array}{c}\text { Min- } \\
\text { Maks }\end{array}$ & Lower & Upper \\
\hline $\begin{array}{c}\text { Kesiapsiaga } \\
\text { an Siswa }\end{array}$ & 75 & 56,20 & 3.029 & $14-27$ & 55,46 & 57,65 \\
\hline
\end{tabular}

Berdasarkan tabel 3.2 didapatkan rata-rata KesiapsiagaanSiswa SMPN13 Padang setelah diberikan penyuluhan adalah 56,20dengan Standar Deviasi 3,029. Tingkat Pengetahuan yang rendah 14 dan tertinggi 27. Hasil estimasi dapat disimpulkan bahwa $95 \%$ diyakini rata-rata kesiapsigaan adalah antara 55,46 sampai dengan 57,65.

\section{b. Analisis Bivariat}

Analisisa bivariat bertujuan untuk melihat adanya pengaruh penyuluhan kesehatan terhadap kesiapsiagaan menghadapi bencana gempa bumi pada Siswa SMPN 13 Padang, terlihat pada tabel berikut ini:

Tabel 3.3

Distribusi Frekuensi Pengaruh Kesiapsiagaan Menghadapi Bencana Gempa Bumi Sebelum dan Sesudah Diberikan Penyuluhan pada Siswa SMPN 13 Padang.

\begin{tabular}{cccccc}
\hline Variabel & Mean & SD & SE & P value & N \\
\cline { 1 - 3 } $\begin{array}{c}\text { Kesiapsiagaan } \\
\text { Siswa Sebelum }\end{array}$ & 17.36 & 3.463 & 0.400 & & 0,000 \\
\cline { 1 - 3 } $\begin{array}{c}\text { Kesiapsiagaan } \\
\text { Siswa Sesudah }\end{array}$ & 56,20 & 3.029 & 0.350 & & 75 \\
\hline
\end{tabular}

Berdasarkan tabel 3.3 di atas dapat dilihat bahwa didapatkan rata-rata kesiapsiagaan pada pengukuran pertama 17,36 dengan standar deviasi 3,463. Pada pengukuran Kedua didapat rata-rata kesiapsiagaan 56,20 dengan standar deviasi 3.029. Telihat nilai mean perbedaan pada pengukuran pertama dan kedua adalah 38,66 . Hasil uji statistik didapatkan nilai $p$ value 0,000 $(\mathrm{P}<0,05)$ maka dapat disimpulkan ada pengaruh atau perbedaan yang singnifikan antara pengukuran kesiapsiagaan menghadapi bencana pada Siswa SMPN 13 Padang pada pegukuran pertama dan kedua

\section{PEMBAHASAN}

A. Analisi Univariat

\section{Kesiapsiagaan Sis wa Menghadapi Bencana Gempa}

\section{Bumi Sebelum Diberikan Penyuluhan}

Hasil penelitian menjelaskan bahwadidapatkan rata-rata kesiapsiagaan Siswa SMPN13 Padang dalam menghadapi bencana gempa bumi pada pretest adalah 17,36 dengan Standar Deviasi 3,46 dengan tingkat pengetahuan yang rendah 9 dan tertinggi 26. Hasil estimasi dapat disimpulkan bahwa $95 \%$ diyakini ratarata kesiapsiagaan siswa dalam menghadapi bencana gempa bumi adalah antara 16,56 sampai dengan 18,16 .

Hasil penelitian ini sama dengan hasil penelitian yang dilakukan oleh Sisiana Besti Emami tahun 2015, dengan hasil adanya pengaruh kesiapsiagaan 
menghadapi bencana gempa bumi pada Siswa SD Muhammadiyah Trisigan Murtigading Sandel Bantul dengan hasil uji paired sample t-testnya menunjukkan nilai Pvalue0,000. Selain itu hasil penelitian ini juga didukung dengan hasil penelitian lainnya yang dilakukan oleh Riedel Jiemly dkk dengan hasil penelitian ada pengaruh penyuluhan kesehatan terhadap kesiapsiagaan bencana gempa bumi pada Siswa SMP Kristen Kakaskaseh Kota Tumohon Tahun 2015 dengan nilai Pvalue 0,000.

Secara teori kesiapsiagaan adalah tindakantindakan yang memungkinkan pemerintah, organisasi, masyarakat, komunitas dan individu untuk mampu menanggapi suatu situasi bencana secara cepat dan tepat guna. Termasuk kedalam tindakan kesiapsiagaan adalah penyusunan rencana penanggulangan bencana, pemeliharaan dan pelatihan personil. Kesiapsiagaan merupakan upaya yang dilaksanakan untuk mengantisipasi kemungkinan terjadinya bencana guna menghindari jatuhnya korban jiwa, kerugian harta benda, dan berubahnya tata kehidupan masyarakat. Sebaiknya setiap instansi melakukan kesiapsiagaan (Nugroho, 2007). Kesiapsiagaan bisa dilakukan apabila peran antara pemerintah dan instansi terkait dilakukan dengan baik. Sesuai dengan tuntutan Undang-undang dan peraturan yang dikeluarkan oleh BNPB No.4 Tahun 2012 tentang "Pedoman Penerapan Sekolah/Madrasah Aman dari Bencana" telah direncanakan dan dilaksanakan upaya-upaya untuk memberikan ilmu pengetahuan serta skill kepada beberapan sekolah/madrasah yang ada di Indonesia termasuk Kota Padang.

SMPN 13 Padang merupakan SMPN yang sudah pernah mendapatkan sentuhan atau materi ilmu pengetahuan tentang mitigasi bencana oleh BPBD Kota Padang, dan terakhir ilmu itu didapatkan hanya untuk kelas 8 dan 9. Sehingga untuk penelitian yang dilakukan peneliti sekarang hanya melibatkan kelas 7 saja. Sebelum penyuluhan diberikan oleh BPBD maka dilakukan terlebih dahulu pretest untuk melihat kemampuan dari pada siswa dalam siaga bencana gempa bumi. Secara teori dikatakan setiap individu yang belum pernah tersentuh dengan ilmu baru maka pengetahuan yang dimiliki akan rendah dibandingkan dengan yang sudah memiliki pengetahuan (Burnie D, 2015). Teori ini terbukti dengan hasil penelitian yang peneliti dapatkan, setelah peneliti melakukan analisa terhadap hasil pretest yang sudah dikerjakan oleh siswa terlihat bahwa masih banyak siswa yang tidak memahami konsep dari pada kesiapsiagaan menghadapi bencana gempa bumi. Ini terlihat dari hasil rata-rata pretest siswa adalah 17,36 dari 75 orang siswa yang diambil menjadi sampel dalam penelitian.

Berdasarkan analisa yang dilakukan peneliti dalam jawaban siswa pada item kuesioner yang diberikan, terlihat pada konsep pengetahuan siswa banyak tidak memahami pertanyaan nomor satu yang menyatakan pengertian dari bencana. Artinya secara konsep atau teori siswa masih lemah dengan pegetahuan bencana. Tidak hanya itu pertanyaan tentang apa yang dilakukan jika terjadi bencana gempa disekolah masih banyak yang kurang memahami, sehingga peneliti merasa sangat perlu dilakukannya penelitian ini. Item lainnya yang peneliti lihat pada kelompok kuesioner tentang rencana kegiatan dari bencana tergambar siswa tidak memahami tentang persiapan apa saja yang harus dilakukan sebelum terjadinya bencana. Selanjutnya pada item kelompok kuesioner tentang peringatan bencana, masih banyak siswa yang tidak faham apa saja tanda-tanda peringatan tsunami setelah kejadian gempa bumi yang diketahui, pada umumnya siswa hanya menyebutkan alarm. Berikutnya dalam kelompok kuesioner mobilisasi sumber daya, didapatkan masih banyak siswa yang tidak mengerti tentang apa saja keterampilan yang perlu disampaikan kepada tementemen sekolah tentamg siaga bencana.

Semua dari uraian yang peneliti jelaskan dapat disimpulkan bahwa kesiapsiagaan siswa SMPN 13 sebelum mendapatkan penyuluhan masih sangat kurang. Hal ini bisa dilihat dari beberapa uraian pertanyaan yang sudah diberikan peneliti kepada siswa. Pada peneltian lainnya yang dilakukan juga didapatkan kesamaan dengan hasil yang dilakukan peneliti. Kesiapsiagaan merupakan modal utama bagi masyarakat baik institusi maupun sekolah untuk menjadi modal dalam menyelamatkan diri sendiri dan orang lain. Jika ilmu tentang mitigasi bencana sudah didapatkan maka perencanaan siswa dalam menghadapi bencana gempa bumi akan lebih matang.

\section{Kesiapsiagaan Sis wa Menghadapi Bencana Gempa}

\section{Bumi Sesudah Diberikan Penyuluhan Mitigasi}

\section{Bencana}

Hasil penelitian menjelaskan bahwa rata-rata Kesiapsiagaan Siswa SMPN13 Padang setelah diberikan penyuluhan adalah 56,20 dengan Standar Deviasi 3,029. Tingkat Pengetahuan yang rendah 14 
dan tertinggi 27. Hasil estimasi dapat disimpulkan bahwa 95\% diyakini rata-rata tingkat pengetahuan adalah antara 55,46 sampai dengan 57,65.

Hasil penelitian ini sama dengan penelitian yang dilakukan oleh Indria Santoso S.Budi dkk Tahun 2015 yang menyebutkan adanya pengaruh pendidikan kesehatan terhadap kewaspadaan bencana alam di Dusun Kantong Desa Kemiri Kecamatan Panti Kabupaten Jember dengan nilai Pvlaue adalah 0,000. Penelitian lainnya yang mendukung hasil peneltian peneliti adalah yang dilakukan oleh Pribadi K.S Tahun 2009 menyampaikan bahwa ada pengaruh pendidikan kesehatan terhadap mitigasi bencana di SDN Cirateun dan SDN Padasuka Kabupaten Bandung dengan nilai Pvalue 0,000.

Gempa bumi adalah bergoncangnya bumi yang disebabkan oleh tumbukan antar lempeng bumi, aktivitas gunung api dan reruntuhan batuan (BNPB, 2012). Salah satu daerah yang rawan akan bencana gempa bumi adalah Sumatera Barat tepatnya di Kota Padang. Di pesisir pantai Kota Padang masih banyak sekolah-sekolah yang harus mendapatkan perhatian khusus untuk menghadapi bencana gempa bumi, yang upaya salah satunya adalah Kesiapsiagaan bencana.kesiapsiagaan menurut Nugroho (2007) kesiapsiagaan adalah tindakan-tindakan yang memungkinkan pemerintah, organisasi, masyarakat, komunitas dan individu untuk mampu menanggapi suatu situasi bencana secara cepat dan tepat guna. Salah satu yang harus diperhatikan untuk mengurangi resiko pasca bencana adalah penyuluhan kesiapsiagaan bencana pada siswa SMPN 13 Padang yang lokasinya juga dekat dengan pantai dan bangunan yang bertingkat.

Tujuan dari dilakukannya penyuluhan kesiapsiagaan adalah untuk mempersiapkan diri siswa untuk menghadapi bencana dan mengurangi resiko korban setelah terjadinya bencana. Berdasarkan hasil penelitian yang peneliti lakukan setelah diberikannya penyuluhan tentang kesiapsiagaan menghadapi bencana gempa bumi oleh BPBD didapatkan hasil siswa terlihat mulai memahami tentang item-item penting yang diperlukan dalam menghadapi bencana seperti yang dijelaskan oleh BPBD. Item penting diantaranya adalah ; pengetahuan tentang kesiapsiagaan bencana, rencana kegiatan dari bencana, peringatan bencana, dan mobilisasi sumber daya.

Pada hasil postest mahasiswa memiliki pemahaman yang bagus pada setiap kelompok item pertanyaan. Ini diperoleh dari keseriusan siswa dalam mendapatkan ilmu tentang kesiapsigaan menghadapi bencana yang diberikan oleh BPBD Kota Padang. Hal ini juga dibuktikan dengan didapatkannya rata-rata nilai siswa adalah 56,20. Berdasarkan analisa peneliti, siswa akan memiliki pengetahuan kesiapsiagaan yang baik jika mampu mengikuti materi yang diberikan dengan sungguh-sungguh. Selain itu siswa jugan serius dalam menerapkan apa yang sudah di pahami dalam penyuluhan yang diberikan. Mampu mentransferkan ilmu yang didapatkan kepada teman dan masyarakat lainnya disekitar kita. Resiko pasca bencana akan berkurang jika semua aspek masyarakat sudah mengetahui, memahami dari pada kesiapsiagaan bencana gempa bumi.

\section{B. Analisa Bivariat}

\section{Pengaruh Kesiapsiagaan Menghadapi Bencana Gempa Bumi Sebelum dan Sesudah Diberikan Penyuluhan}

Berdasarkan hasil penelitian didapatkan rata-rata kesiapsiagaan pada pengukuran pertama 17,36 dengan standar deviasi 3,463. Pada pengukuran Kedua didapat rata-rata kesiapsiagaan 56,20 dengan standar deviasi 3.029. Telihat nilai mean perbedaan pada pengukuran pertama dan kedua adalah 38,66. Hasil uji statistik didapatkan nilai $\mathrm{p}$ value $0,000(\mathrm{P}<0,05)$ maka dapat disimpulkan ada pengaruh atau perbedaan yang singnifikan antara pengukuran kesiapsiagaan menghadapi bencana pada Siswa SMPN 13 Padang pada pegukuran pertama dan kedua.

Hasil penelitian ini sama dengan penelitian yang dilakukan oleh Riedel Jiemly dkk dengan hasil penelitian ada pengaruh penyuluhan kesehatan terhadap kesiapsiagaan bencana gempa bumi pada Siswa SMP Kristen Kakaskaseh Kota Tumohon Tahun 2015 dengan nilai Pvalue 0,000. Penelitian lainnya yang sama yaitu yang diteliti oleh Indria Santoso S.Budi dkk Tahun 2015 yang menyebutkan adanya pengaruh pendidikan kesehatan terhadap kewaspadaan bencana alam di Dusun Kantong Desa Kemiri Kecamatan Panti Kabupaten Jember dengan nilai Pvlaue adalah 0,000.

Menurut Undang-undang Republik Indonesia Nomor 24 pasal 1 Tahun 2007 Bencana adalah peristiwa yang mengancam dan mengganggu kehidupan dan penghidupan masyarakat yang disebabkan baik oleh faktor alam atau non alam sehingga mengakibatkan timbulnya korban jiwa 
manusia, kerusakan lingkungan, kerugian harta benda dan dampak psikologis (BNPB, 2008). Salah satu bencana yang mengganggu dalam kehidupan dan berdampak sangat besar adalah bencana alam. Bencana alam adalah serangkaian peristiwa yang disebabkan oleh alam, antara lain gempa bumi, tsunami, gunung meletus, banjir, kekeringan, angin topan dan tanah longsor.

Bencana alam yang sangat mengganggu salah satunya adalah gempa bumi, gempa bumi adalah merupakan suatu peristiwa lepasnya energi yang menyebabkan pergeseran pada bagian dalam bumi secara tiba-tiba. Mekanisme perusakan terjadi karena energi getaran gempa dirambat keseluruh bagian bumi. Salah satu yang harus dilakukan segera mungkin untuk menghindari resiko besar terhadap gempa bumi adalah melakukan penyuluhan kesiapsiagaan.

Berdasarkan peraturan BNPB No.4 Tahun 2012 tentang "Pedoman Penerapan Sekolah/Madrasah Aman dari Bencana" telah jelas disampaikan bahwa sekolah dan madrasah merupak sasaran utama dalam melakukan pendidikan kesehatan tentang kesiapsiagaan. Seperti yang dilakukan oleh peneliti di SMPN 13 Padang. Penelitian ini adalah kerjasama antara STIKes Alifah dengan BPBD Kota Padang. Pada penelitian ini memang langsung mendatangankan tenaga ahli dalam penelitian ini, tujuannya agar ilmu dan informasi yang diberikan betul-betul yang sesuai dan sudah diatur oleh Neagara.

Berdasarkan hasil analisis peneliti dalam penelitian ini terlihat adanya perbedaan antara kesapsiagaan siswa sebelum dan sesudah dilakukan penyuluhan. Ini dibuktikan dengan nilai rata-rata pretest adalah 17.36 dengan SD 3.46 dan rata-rata nilai posttest adalah 56,20 dengan SD 3,02. Jadi perbedaan rata-rata pretest dan posttest adalah 38,66 dengan nilai Pvalue 0,000. Artinya ada pengaruh kesiapsiagaan menghadapi bencana gempa bumi sebelum dan sesudah diberikan penyuluhan pada Siswa 13 Padang.

Pada jawaban siswa di kuesioner juga terlihat bahwa jawaban nilai posttest lebih bagus dibandingkan dengan pretest. Hal ini membuktikan bahwa seseorang akan memiliki kemampuan yang lebih apabila diberikan atau ditransferkan ilmu baik berupa penyuluhan kesehatan. Tidak hanya itu berdasarkan hasil pengamatan peneliti setelah diberikan penyuluhan siswa juga banyak tanya jawab dengan narasumber seputar gempa bumi. Melihat hal ini peneliti merasakan masih perlu meningkatan selanjutnya tentang pelatihan atau simulasi kesiapsiagaan menghadapi bencana gempa bumi.

\section{KESIMPULAN}

Setelah dilakukan penelitian tentangpengaruh penyuluhan kesehatan terhadap kesiapsiagaan menghadapi bencana gempa bumi pada Siswa SMPN 13 Padang, maka dapat disimpulkan :

1. Rerata sebelum diberikan penyuluhan kesehatan terhadap kesiapsiagaan menghadapi bencana gempa bumi pada Siswa 13 Padang adalah 17,36 dengan Standar Deviasi 3,46 dengan tingkat pengetahuan yang rendah 9 dan tertinggi 26

2. Rerata sesudah diberikan penyuluhan kesehatan terhadap kesiapsiagaan menghadapi bencana gempa bumi pada Siswa 13 Padang adalah 56,20 dengan Standar Deviasi 3,029 dengan tingkat pengetahuan yang rendah 14 dan tertinggi 27

3. Ada pengaruh atau perbedaan yang singnifikan antara pengukuran kesiapsiagaan menghadapi bencana pada Siswa SMPN 13 Padang pada pegukuran pertama dan kedua.

Disarankan kepada pihak sekolah membentuk tim kesiapsigaan bencana dan meningkatkan keterampilan tentang gempa bumi dan mitigasinya mengingat lokasi sekolah yang berdekatan dengan pantai.

\section{DAFTAR PUSTAKA}

1. Andri Nurudin, 2015. Jurnal Pengaruh Pelatihan Penanggulangan Bencana Gempa Terhadap Pengetahuan Siswa Kelas X IPS.

2. Bakornas PB, 2014. Pengenalan Karakteristik Bencana Dan Upaya Mitigasinya Di Indonesia, Jakarta. Badan Nasional Penanggulangan Bencana

3. BNPB, 2007. Undang-undang No. 24 Tahun 2007 Tentang Penanggulangan Bencana, Jakarta.

4. BNPB, 2008. Pedoman Penyusunan Rencana Peananggulangan Bencana.

5. BNPB, 2012. Potensi Ancaman Bencana. http://bnpb.go.id. Diakses tanggal 18 Desember 2017.

6. BNPB, 2014. Peran Serta Masyarakat Dalam Penyelenggaraan Penanggulangan Bencana.

7. Chairumi, 2013. Pengaruh Konsep Diri Dan Pengetahuan Siswa Terhadap Kesiapsiagaan Bencana Gempa Bumi di SDN 27 dan MIN Merduati Banda aceh. 
8. Deutsche Humanitare, 2015. Kesiapsiagaan Bencana The Johanniter International Asisstance Cabang Papua.

9. Depkes RI, 2006. Keputusan Menteri Kesehatan Republik Indonesia Tentang Siklus Penanggulangan Bencana.

10. Depkes RI, 2009. Pedoman Penanggulangan Bencana Bidang Kesehatan.

11. Depkes, RI, 2010. Pedoman Penanggulangan Bencana Bidang Kesehatan

12. Diposatono, 2013. Tsunami. Buku Ilmiah Populer.

13. Drra (Disaster Risk Reduction Aceh), 2011. Strategi Peningkatan Kesadaran Publik Dalam Pengurangan Resiko Bencana Aceh 2011-2015.

14. Emami, Sinsiana Besti (2015) Pengaruh Penyuluhan Kesiapsiagaan Menghadapi Bencana Gempa Bumi terhadap Pengetahuan Siswa di SD Muhammadiyah Trisigan Murtigading Sanden Bantul.

15. Firmansyah, I. 2014. Hubungan Pengetahuan Dengan Perilaku Kesiapsiagaan Dalam Menghadapi Bencana Banjir dan Longsor Pada Remaja Usia 15-18 Tahun di SMA Al-Hasan Kemiri Kecamatan Panti Kabupaten Jember.http://journal.unair.ac.id

16. Fima \& Sudaryono, 2012. Perbedaan Kesiapsiagaan Menghadapi Bencana Ditinjau Dari Tingkat Self-Efficacy Pada Anak Usia Sekolah Dasar Di Daerah Danpak Bencana Gunung Kelud.

17. Japanase Red Cross Society, 2009. Keperawatan Bencana, Banda Aceh : Kerjasama Palang Merah Jepang-Palang Merah Indonesia.

18. Konsorsium Pendidikan Bencana, 2011. Kerangka Kerja Sekolah Siaga Bencana.

19. Lipi-Unesco, 2006. Kajian Kesiapsiagaan Masyarakat Dalam Mengantisipasi Bencana Gempa Bumi \& Tsunami, Jakarta. Deputi Ilmu Pengetahuan Kebumian Lembaga Ilmu Pengetahuan Indonesia.

20. Makahanap M.P dkk, 2013. Pengaruh Penyuluhan Kesehatan.

21. Notoadmodjo, 2007. Promosi Kesehatan: Teori \& Aplikasinya, Jakarta. Rineka Cipta.

22. Nugroho, C. 2007. Kajian Kesiapsiagaan Masyarakat Dalam Mengantisipasi Bencana Gempa Bumi Dan Tsunami Di Nias Selatan. http://unecdoc.unesco.org

23. Nursalam, 2011. Manajemen Keperawatan : Aplikasi Dalam Praktek Keperawatan Profesional. Edisi 3. Jakarta; Salemba Medika.
24. Pranajati, 2013. Upaya Madrasah Dalam Membangun Hard dan Soft Skill Siswa Dalam Kesiapsiagaan Terhadap Bencana.

25. Peraturan Kepala Badan Penanggulangan Bencana Nasional Tahun 2008.

26. Pribadi K \& Yuliawati A, 2009. Pendidikan Siaga Bencana Gempa Bumi Sebagai Upaya Meningkatkan Keselamatan Siswa.

27. Dien, Riedel Jiemly, 2015. Pengaruh Penyuluhan Kesehatan Terhadap Kesiapsiagaan Menghadapi Bencana Gempa Bumi Pada Siswa Smp Kristen Kakaskasen Kota Tomohon. Jurnal Keperawatan Vol 3, No 2 (2015): E-Jurnal Keperawatan

28. S.Budi Santoso, dkk (2015) Pengaruh Pendidikan Kesehatan Terhadap Kewaspadaan Bencana Alam Dusun Kantong Desa Kemiri Kecamatan Panti Kabupaten Jamber. http://digilib.unmuhjember.ac.id/files/disk1/70/umj1x-sbudisanto-3481-1-artikel-1.pdf

29. Setyadi, 2012. Konsep dan Praktik Penulisan Riset Keperawatan. Yogjakarta; Graha Ilmu.

30. Supriyono, 2014. Seri Pendidikan Pengurangan Risiko Bencana Gempa Bumi.

31. Syafrizal, 2013. Filsafat Ilmu dan Metode Riset.

32. Undang-undang No. 24 Tahun 2007 Tentang Penanggulangan Bencana.

33. Zamroni, M.I, 2011. Jurnal Penanggulangan Bencana Volume 2 No. 1. Jakarta; BNPB. 